\title{
Strategy For Financial Wellbeing Among Public Servants In Malaysia
}

\author{
Nurul Najwa Wahab, ${ }^{1^{*}}$ Zulnaidi Yaacob $^{2}$ \\ ${ }^{1}$ Ministry of Health, MALAYSIA \\ ${ }^{2}$ Universiti Sains Malaysia, Penang, MALAYSIA \\ *Corresponding Author
}

DOI: https://doi.org/10.30880/jts.2018.10.02.008

\begin{abstract}
This study is aimed at investigating the determinant factors of financial wellbeing among public servants in Malaysia. To achieve the said objective, three independent variables that are widely discussed in the literature were tested, namely, financial literacy, financial management and attitude towards savings. To complete the study, a total of 139 questionnaires were collected using simple random sampling. Based on regression analysis, this study found that all three determinant factors understudy had significant relationship with financial wellbeing. The findings of this study are supported by most of previous studies. This study, however, has successfully filled in the literature gap by presenting evidence of determinant factors of financial wellbeing among public servants of emerging economy that are still not well addressed in the literature. The implications of this study are also discussed.
\end{abstract}

Keywords: Financial wellbeing, public servants, financial management

\section{Introduction}

Individual financial well-being has been a subject of interest of researchers from a diverse discipline covers finance, sociology, public policy, and economics due to financial wellbeing is regarded a social challenge of people from developed and developing countries that requires a comprehensive framework to address it. Both developed and developing countries are facing different issue on financial management of their people. While the developing countries seeing the increasing number of middle class society group that are participating in new growing financial market, a more developed nation is now facing challenge with the emergence of financial technology that's make financial issue become wider and more complex (Kaur et al., 2013). All this continuing issue related to financial wellbeing has contributed to the development of different streams of financial wellbeing literature, which is still growing. 
As such, there are studies investigating the factors of financial wellbeing (e.g: Gaisina \& Kaidarova, 2017), while others investigating the consequences of financial wellbeing (e.g: Barbic, Palic \& Bahovec, 2016). The issue is becoming more critical with the increasing number of pensioners across nation, higher number of productive workers in the job market and also higher number of reported case in relation to personal debt, poor financial management and improper financial planning. Low birth rate is another reason quoted as pushing factor for more concern on individual financial wellbeing of people, such as in Taiwan (Hsiao et al., 2016).

In addition to researchers at university, the study and census on financial wellbeing among people in Malaysia has also been conducted at national level involves bigger samples and conducted by public institution like Department of Statistics, Malaysia. This huge attention given by many parties reflects the utmost important of the issue of individual financial well-being as the issue is not only about individual or institutional matters but a national and global issues as well. As noted by Hsiao et al. (2016), individual financial wellbeing is also a prerequisite of nation social stability. Instead, an individual with unsatisfactorily financial wellbeing will not only become a burden to themselves or their immediate circles but indirectly will have an impact on the health of economic and financial systems of a country. The negative effect to the nation is because people with financial difficulties may have negative impact on their

productivity, physical health, economic and psychology (Kaur et al., 2013). Barbic et al. (2016) highlighted that people living in poverty will become dependent to the government welfare program. Therefore, realizing the important of individual financial wellbeing towards a nation wellbeing, the government of Latvia had considered people financial literacy as a national agenda (Ciemleja, 2016), the step taken by many other countries including Malaysia.

Therefore, investigating the issue of individual financial wellbeing is not only about scientific endeavor in findings a solution for individual level problem but a world strategic issues, and the issues is also very much relevant to Malaysia, a country with increasing number of aging population. However, the number of studies on the financial behavior related issues among developing nation is still scarce and limited (Nguyen et al., 2017) thus calling for more research to be done in order to shed lights on still unattended or less explored research issues, among other is financial wellbeing of public servant which become the central focus of this present study.

The Malaysian Department of Statistics reported the life expectancy of Malaysian at 74.8 years old in 2017, increase from 74.3 years in 2011. The trend is expected to be upwards in future because of the advancement in medical breakthrough and technology, health awareness and better quality of life for Malaysians, a country which is progressively moving toward position itself as a developed country in the near future. A higher number of post working age citizens means more people will live without active income and more critical on having a wellbeing financial status during their older age for supporting their necessary expenses including medical expenses. Recognizing the important of financial wellbeing as a component of human wellbeing, few researchers did study on this issue such as Barbic et al. (2016); Husna et al. (2012) and Mohamad and Teo (2014).

Among the major stream of these studies is developing a model to reveal the determinants of financial wellbeing with more focus on the students, women and employees as the subject of interest. Each group of subjects has their unique financial issues and challenges thus deserved a study with different methodology and theoretical discussion to be executed. One important group of subjects that is not well addressed in the literature is public servant, with a very limited attention was given by scholars. Public servant in Malaysia is regarded as unique group of employees compared to the employees of private sectors as they entitled for pensions during their retirement and thus this secured mindset may have an impact on their attitude towards financial wellbeing which is remained less explored. However, the amount they received as their pension is only at maximum amount of $60 \%$ of the last day basic salary, thus makes the issue of financial wellbeing is still critical. An effort to study financial wellbeing among public servants in Malaysia was carried out by Sabri and Juen (2014). However the study was limited to women, thus call for study involving both men and women respondents because the issue of financial wellbeing is not limited to any gender.

The small number of research on the issue of determinants of financial wellbeing published by Malaysian scholars is a gap that requires urgent attention. A simple search on Malaysian journal database of Myjurnal using article title of 'financial wellbeing' as searching key word revealed that only one research article was available from the database. Although the database doesn't not perfectly represents the number of studies using Malaysian samples, the database covers almost all journal published by institutions in Malaysia. Therefore, the situation indicated a huge gap on financial wellbeing literature particularly in Malaysian literature. Thus an urgent attention from Malaysian researcher is now undebatable. An improved knowledge on this will allow relevant stakeholders to take necessary and suitable intervention actions in improving the financial well being among Malaysians. Strategies in developing a society with a better financial wellbeing are not limited to providing subsidy, financial assistance or financial education at young age. What is more important is for government to establish a comprehensive framework that a result of a well understanding on the issue of individual financial wellbeing. As financial wellbeing is a result of successful financial planning and management and 
Nurul Najwa Wahab1 et al., Journal of Techno Social Vol. 10 No. 2 (2018) p. 50-59

right individual financial attitude, it requires a long-term perspectives in changing individual knowledge, attitude and behavior towards financial wellbeing. The long term time frame required in achieving financial wellbeing has been asserted by scholars where the financial wellbeing of a person is an outcome of literacy on financial matters which is gained since the early age (Jappelli \& Padula, 2015) such as be literate in the financial concept of interest, time value of money, shares and risk (Pudlo \& Gavurova, 2012). The present study is useful particularly in the context of a developing nation, in understanding what make Malaysian people have a better financial wellbeing as previous study among Malaysian respondents revealed that only a quarter of respondents in their study were savings for retirement needs (Sabri \& Juen, 2014). In addition, a significant number of retirees had been found to have financial problem (Husna et al., 2012).

Despite many variables may predict the financial wellbeing, this study focuses on financial literacy, financial management and attitude towards savings. All these three predictors, although has been widely discussed in the literature but they received scant attention from researchers of developing nation. For instance, Kulikov et al. (2007) mentioned little has been revealed about saving attitude among people in developing countries. While financial literacy in developed countries is generally at satisfactory level, the situation in developing countries is different. As reported by Barbic et al. (2016), Croatians in their study were not aware that their financial literacy would have an impact on their financial wellbeing during retirement period.

\section{Problem Statement}

The financial problem among Malaysian is not a symptom or anecdote. Instead, it is a real current society problem that needs urgent attention. A study by Jariah et al. (2012) among elderly in Malaysia confirmed that financial problem strike a significant number of them involving financial problem related to daily and credit management. Not only is a problem among retirees, financial problem is an untoward situation among productive employees. The financial wellbeing condition among women public servant in Malaysia is not at high level and this condition had resulted case like people were unable to consistently provide adequate funds in meeting their living needs (Sabri \& Juen, 2014). The unsatisfactory level of financial wellbeing is not a unique problem of public servants in Malaysia, but global phenomenon involved other countries like India and South Africa . Financial wellbeing is also in doubt among professional if the capability of financial management among future technocrat is an alarming symptom for a chronic financial condition. The future technocrat in India admitted their incapability in managing their personal financial (Sood et al., 2012) while in South Africa, households are found to be over-indebted (Koloba, 2018)

Despite the literature on financial wellbeing are ubiquitous, few critics emerged in which leading to a call for more research on the issues. As such the measurement of financial wellbeing in literature differs from one study to another study in which makes the implication of research findings must be applied with cautious. The different is not only in the items used to measure the construct but the approach taken by different researchers, such as the variation between usage of single item and multiple items to measure the construct of financial wellbeing (Joo \& Grable, 2004). In addition to methodology issues, study on determinants of financial wellbeing in emerging economies like Malaysia is relatively scarce, thus calling for more research to address this literature gap. For example, studies on financial literacy in the context of developing country is still limited (Gaisina \& Kaidarova, 2017) and the literature is still facing problem of having a definite valid measurement of financial literacy that can be adapted to different context of study (Ciemleja, 2016). Among others, the issue is related to the multidisciplinary approach of investigating financial literacy that supported by different theoretical background.

Consistent with the background of the issue understudy, this study aims to answer the following research question: What are the determinants of financial wellbeing among public servants in Malaysia? Due to many variables may become the determinants of financial wellbeing, this study focuses on these three predictors which are widely mentioned in the literature, namely financial literacy, financial management and attitude towards savings. Therefore, the following research objective has been set: To examine the relationship between financial literacy, financial management and attitude towards savings and financial wellbeing.

\section{Leading to Financial Wellbeing}

Wellbeing is a complex theoretical construct used to define the condition of individual, family, organization, country or even the world in meeting the basic needs of life. It encompasses various elements including physical, psychological, social and financial wellbeing (Zemtsov \& Osipova, 2015) and all are connected to each other. Wellbeing in all these elements would contribute to total human wellbeing, which is the necessary of each and all of us. However, this study concerns on financial wellbeing of public servants in line with the discussion narrated in the section of background and problem statement of this study. The interrelated nature of elements of total human wellbeing make the findings of this present study is not only significant in improving financial wellbeing but also will have a subsequent effect on the other elements of human wellbeing. 
The condition of individual financial wellbeing is related to the individual attitude toward financial management (Gasiorowska, 2015). Therefore, financial wellbeing could be considered as a financial objective that are achievable and under controlled of each individual. In other words, a person would be able to achieve a financial wellbeing by improving knowledge on financial management and revisit their savings decision making. Due to financial wellbeing is a result of effective financial management, one main stream of studies on predictive factors of financial wellbeing is investigating subjective measures of financial management. Another main stream of literature focuses on more objective variables such as data on income, debt, asset and total wealth in predicting financial wellbeing. Despite the latter approach revealed the relationship between objective financial data and subjective financial wellbeing, the literature on this is not free from critics such as findings of studies are varies across different economic region and financial wellbeing should not be limitedly defined as equal to total financial wealth (Gasiorowska, 2015). Instead, financial wellbeing is a psychological condition of individual that are happy and satisfy with their financial condition at a various amount of money due to different in person's values, needs and wants (Gasiorowska, 2015). While the latter approach is more specific to financial data, the first research stream focuses on the attitude of person that may have an impact on their financial wellbeing.

Investigating the financial wellbeing of public servant is not only a relevant subject to the individual but the organization too as Gasiorowska (2015) reviewed the literature and concluded that the literature had well addressed the impact of individual financial wellbeing on job productivity. In other words, individual with financial problem may tend to create untoward work related problem to their organization. Individual who are trapped into financial problem may have any or both of these problem; chronic financial problem or acute financial problem (Pierce \& Hanna, 1996). Chronic financial problem refers to a series of financial related problem of individual such as did not able to pay for food, rent or other needs. Acute financial problem is a sudden serious financial problem that require individual to find help or borrow money from other parties such as welfare and banks. With all these problems, an individual may have difficulty in functioning as normal employees at their workplace. In other words, financial wellbeing of an employee is no doubt will have an impact on organization productivity which in turn risk the nation and global productivity.

\section{Financial Literacy}

Financial literacy is an essential life skill for individual to achieve financial wellbeing and each individual should be a literate person in financial as early as possible and more importantly at their early career age (Kaur et al, 2013). The more financial related decision they make, the more they need to be literate in financial matters. As defined by Huston (2010), financial literacy is ability to understand and apply financial concept that are relevant for financial decision making in achieving financial wellbeing. As such, individual may need to make the decision on investment, mortgage, buying a high value of assets and getting credit and these decision must be made within the informed choice, balance between risk and opportunities and understanding on the financial products. According to Barbic et al. (2016) and Hsiao et al. (2016), a more financially literate individual is more likely to have better financial preparation for retirement days. This is due to their understanding on the consequences of any action in relation to financial wellbeing they may take or ignore. However financial literacy among individual are varies due to certain factors such as education background and experience in dealing with financial matters. As such, Sood et al. (2012) claimed that technical graduates are not equipped with adequate financial knowledge to make them a technocrat with a sound financial literacy. However, financial is a dynamic subject where knowledge on it must be revisit continuously. A knowledge learned during university days may be become obsolete in few years later. The reasons why financial education needs to be continuously learned in order to maintain the level of financial literacy, among others, are financial products are always revised with different complexities and new financial products are introduced to market from time to time to accommodate new demands and new market regulations (Sood et al., 2012).

Financial literacy is not only about how well an individual knowledge on all financial matter but how confident an individual in making a well informed decision when it comes to financial decision that matters to him or her. Therefore, an individual with financial literacy can be defined as a person who has ability to read, analyze, manage and communicate about the personal financial matters that may have an impact on their financial wellbeing (Anthes, 2004). In other words, the financial literacy is conceptually contributing to the financial wellbeing of an individual. In contrast, financial illiterate individual is expected to experience more financial problem because Grable et al. (2009) mentioned that individual behavior towards financial is very much related to their financial knowledge. With financial knowledge, individual is more likely to engage in activities contributing to their financial wellbeing such as retirement planning and investment (Barbic et al., 2016; Lusardi, 2008). Another study has also confirmed the link between financial literacy and financial wellbeing among people in Egypt (Shusha, 2016). Without being literate in financial, individual may not understand the changes in the economic and policy systems that may have impact on their financial planning. As a consequence, they will not aware about what the plan and act on financial matter will determine their financial wellbeing in the future (Barbic et al., 2016) 


\section{Financial Management}

How well people manage their money would contribute to their financial wellbeing. Although Ciemleja (2016) considers financial management as a sub-concept of financial literacy, his consideration is still debatable and no consensus has been reported on this in literature. While financial literacy is a measure of knowledge and skills, financial management is a measure of practice and action. Although people with financial literacy would lead to financial management, the case is not always true as financial problem does exist among professional who have professed financial knowledge but yet weak in term of practice and action that lead to mismanagement. Every people have different rate of income thus require an understanding on how to find the balance between income and spending to meet the end needs. Wealth can be measured objectively by the asset someone have but financial wellbeing could be achieved by sound financial management. All Individual need to manage their spending, saving and investment, (Kaur et al., 2013), so to achieve financial wellbeing. The good practice of financial management should begin as early as possible and not waiting until near to retirement age. Although previous study has reported that financial management is positively related to financial wellbeing, the construct of financial management has been measured varies by different researchers (Husna et al, 2012). In Husna et al. (2012), they measured financial management as consist of financial planning, cash management, credit management and investment. It does not visibly cover elements like cash flow management and retirement plan.

In addition, to assure of financial wellbeing, a sound financial management would hinder an individual from overindebted. How individual manage their financial determine their financial condition (Ciemleja, 2016). Poor financial management led to over-indebted or vice versa. The over-indebted situation arise when an individual doesn't have adequate resources to repay their credit or he or she has to lower their standard of living in order to fulfill their credit commitment (Ntsalaze \& Ikhide, 2016).

\section{Attitude Towards Savings}

Savings is important for an individual and family to achieve financial wellbeing, among other individual with adequate savings would be able to have better prepared during emergency days. To be a discipline individual in savings, an individual need to have right savings behavior (Hsiao et al, 2016) because the long term objective of savings would be difficult to achieve without an individual having a strong will. In addition to meeting the need of emergency incidents, savings would be used for retirement expense and vacation (Kozera et al., 2016). In other words, saving is a critical factor for individual and family who aim to increase the financial wellbeing and standard of living in the future. Savings also allow individual to have adequate resource to funding their needs during retirement days such as to pay for daily needs and medical expenses. In their paper, Husna et al. (2012) asserted that inadequate financial resource would lead to financial problem among elderly individual. For this, financial education is crucial in shaping individual attitude towards savings. To make financial education effective, it must use a comprehensive approach involving integrated financial subject into curriculum at school and university, maximize the online platform to provide financial information to the public and expand financial education as a parental developmental education (Sood et al., 2012).

Based on the critical literature assessment and debate narrated above, this study generates the following hypotheses:

H1: There is a relationship between financial literacy and financial wellbeing

$\mathrm{H} 2$ : There is a relationship between financial management and financial wellbeing

H3: There is a relationship between attitude towards savings and financial wellbeing

\section{Methodology}

This section explains the population, sampling frame, sampling techniques and process of data collection. Population of this study is 467 employees of Health Department in Kedah. The decision was made to distribute questionnaire to 150 employees based on the number of responses needed for statistical analysis and taking into consideration the possibilities of incomplete returned form. A rule of thumb on determining sample size for regression analysis, which is the analysis used in this study, is minimum 10 observations per variable. This study has four variables, thus requires at least 40 samples. The 150 potential respondents were selected through simple random sampling. Out of 150 questionnaires distributed, 139 questionnaires were returned and appropriate for further analysis.

Measurement of construct in studying financial wellbeing is still unresolved issue in the literature. As such, until todate there is no standard measurement of financial literacy (Hsiao et al, 2016). However, for the purpose of this study, the questionnaire was adapted from Mohamad and Teo (2014). The main section of questionnaire measures the independent and dependent variables. All variables are measured using five-point Likert scales ranging from scale one to scale five. The definite score for each variable was calculated by averaging the score of all items represent each variable. Therefore, the theoretical range of each variable is between one and five. The higher score indicates higher level of financial literacy, financial management, attitude toward savings and financial wellbeing. In addition to measure the main variables, the section of demography information was also included in the questionnaire to collect data on the background of the respondent. Table 1 tabulates the number of item used to measure each variable.Kerajaan sedang giat mengarusperdanakan agenda wakaf pengajian tinggi dalam negara. Ia berlaku dalam suasana ekonomi negara yang tidak begitu memberangsangkan dan peningkatan kos pembiayaan operasi universiti awam (Ashraf Mohd Ramli dan Mustafa 
Omar 2016). Lebih-lebih lagi seluruh institusi pengajian tinggi awam (IPTA) menghadapi potongan peruntukan sebanyak 2.4 billion dalam bajet 2016. Mendepani isu ini, IPT diseru agar mencari dana sendiri tanpa terlalu bergantung sepenuhnya kepada dana kerajaan dengan mempelbagaikan sumber kewangan termasukah dengan mewujudkan Tabung Endowmen dan Wakaf (University Transformation Programme, Purple Book 2016).

Table 1: Number of items for each variable

\begin{tabular}{lc}
\hline Variables & Number of item \\
\hline Financial wellbeing & 12 \\
Financial literacy & 15 \\
Financial management & 15 \\
Attitude towards savings & $\underline{6}$ \\
\hline
\end{tabular}

\section{Data Analysis and Hypothesis Testing}

This section reports the analysis on data of the study using SPSS. The first component of analysis reports the descriptive statistics of respondent, descriptive statistics of variables, reliability and validity test and ends with regression analysis for hypothesis testing.

Table 2 reports the background of respondents. Majority of respondent which represent $64 \%$ are women. In term of ethnicity, a total of 80.6 percent are Malays and followed by Indian, Chinese and others. More than $70 \%$ of respondent are respondent at age between 30 to 39 years old. Analysis on income distribution revealed that majority of respondents which is $54 \%$ are received monthly salary of between RM1,500 and RM3,000.

Table 2: Background of respondents

\begin{tabular}{llll}
\hline Item & Sub-Item & Total & Percentage \\
\hline Gender & Male & 50 & 36.0 \\
& Female & 89 & 64.0 \\
\hline Ethnic & Malay & 112 & 80.6 \\
& Indian & 9 & 6.5 \\
& Chinese & 8 & 5.8 \\
& Others & 10 & 7.2 \\
\hline Age & Below 29 years old & 23 & 16.5 \\
& 30 to 39 years old & 100 & 71.9 \\
& 40 to 49 years old & 15 & 10.8 \\
& 50 years old and above & 1 & 0.7 \\
\hline Monthly income & Below RM1500 & 6 & 4.3 \\
& RM1500 to RM3000 & 75 & 54.0 \\
& RM3001 to RM4500 & 28 & 20.1 \\
& RM4501 and above & 30 & 21.5 \\
\hline
\end{tabular}

Table 3 summarizes the financial status of respondent of this study. A percentage of 61.2 of respondent has allocated less than $10 \%$ of their monthly salary for savings and about $6.5 \%$ of respondent did not saving at all.

However, only $8.6 \%$ reported they don't have adequate money to support their daily needs. If financial wellbeing refers to the financial capability of individual in meeting their needs, then, at this stage, this study may conclude that the majority of respondent in this study has financial wellbeing. A total of $34.5 \%$ of respondents allocated more than $40 \%$ of their monthly income for repayment of their debts. 
Table 3: Financial status of respondents

\begin{tabular}{llll}
\hline \multicolumn{1}{c}{ Item } & Sub-Item & Total & Percentage \\
\hline \% of monthly income & $0 \%$ & 9 & 6.5 \\
used for saving & $1 \%$ to $<10 \%$ & 85 & 61.2 \\
& $10 \%$ to $<20 \%$ & 32 & 23.0 \\
& $>20 \%$ & 13 & 9.4 \\
\hline Adequacy of monthly & Not adequate at all & 12 & 8.6 \\
income & Adequate for expenses on basic needs only & 44 & 31.7 \\
& Adequate for expenses on basic needs and other extra expenses for & 43 & 30.9 \\
& having better quality of life (such as communication, vacation, & & \\
& leisure) & & \\
& Adequate for all expenses and have balance for savings/investment & 40 & 28.8 \\
\hline \% of monthly income & $0 \%$ & 3 & 2.2 \\
used for debt repayment & $>0 \%$ to $<20 \%$ & 38 & 27.3 \\
& $20 \%$ to $<40 \%$ & 50 & 36.0 \\
& $>40 \%$ & 48 & 34.5 \\
\hline
\end{tabular}

Table 4 reports the mean score and standard deviation of all constructs. The mean score for financial wellbeing is 3.7242/5.000 indicates the financial wellbeing among respondents understudy are satisfactorily. The mean score for financial literacy is 3.8507/5.000 indicates the respondents understudy have a good level of financial literacy. In other words, respondents understudy understand most of the issues relating to financial that important for them to make well informed decision making in financial matter. The mean score for financial management is high with score of 4.0959/5.000. In other words, the respondents understudy has a sound management in managing their financial matters such as set priority of fund usage suitable for their needs. The mean score for attitude towards savings is also high the value of 3.7885/5.000 thus indicating the respondents understudy are having positive attitude towards saving such as in allocating their income for savings and understand the importance of having savings for rainy days.

Table 4: Mean and standard deviation

\begin{tabular}{lll}
\hline \multicolumn{1}{c}{ Construct } & Mean & Standard deviation \\
\hline Financial wellbeing & 3.7247 & 0.87485 \\
Financial literacy & 3.8507 & 0.72645 \\
Financial Management & 4.0959 & 0.70173 \\
Attitude towards savings & 3.7885 & 0.71658 \\
\hline
\end{tabular}

\subsection{Reliability test}

A reliability test was done to check the internal consistency of the construct. The Cronbach Alpha value of 0.60 (Nunnaly, 1978) was used as a benchmark to verify the reliability of the construct. Based on the results, few items were suggested to be dropped to improve the score of Cronbach Alpha. The final score of Cronbach Alpha after deletion of few items are given in Table 5. The results indicate the Cronbach Alpha for all construct has surpassed the benchmark required thus consider reliable for further analysis.

Table 5: Reliability test

\begin{tabular}{lccc}
\hline \multicolumn{1}{c}{ Construct } & Number of item & Deleted item & Cronbach Alpha after item deleted \\
\hline Financial wellbeing & 12 & 1 & 0.963 \\
Financial literacy & 15 & 3 & 0.838 \\
Financial Management & 15 & 6 & 0.920 \\
Attitude towards savings & 6 & 1 & 0.663 \\
\hline
\end{tabular}

\subsection{Correlational analysis}

The correlation between independent variables and dependent variable was tested using Pearson Correlation. Table 6 reports that all independent variables understudy, namely financial literacy, financial management and attitude towards saving have significant correlation with financial wellbeing. The coefficient correlation between financial wellbeing and each independent variable are financial literacy (0.554), financial management $(0.482)$ and attitude towards savings (0.602). However, hypotheses were tested using multiple regression analysis. 
Table 6: Correlational analysis

\begin{tabular}{ll}
\hline Construct & Financial Wellbeing \\
Financial literacy & $0.554^{*}$ \\
Financial management & $0.48^{*}$ \\
Attitude towards savings & $0.602 *$
\end{tabular}

\subsection{Hypothesis testing}

Table 7 reports the result of hypothesis testing. The examination on value of VIF (Variance Inflation Factor) indicated there was no serious problem on multicollinearity, thus indicate the independency between the independent variables. The values are all below 10.0 (Hair et al., 1995). It is an assumption for multiple regressions. Based on the results, the $\mathrm{H} 1, \mathrm{H} 2$ and $\mathrm{H} 3$ were supported. Thus, this study accepted the hypothetical relationship between financial literacy and financial wellbeing, financial management and financial wellbeing, and attitude towards savings and financial wellbeing. The relationship between financial management and financial wellbeing is the strongest relationship $(\beta=.470$; $\mathrm{p}$ value $=0.000)$ followed by financial literacy $(\beta=.240 ; \mathrm{p}$ value $=0.000)$ and attitude towards savings $(\beta=.226 ; \mathrm{p}$ value $=0.001)$. The adjusted R2 is 0.620 , thus indicate that $62.2 \%$ of variance of financial wellbeing is explained by financial literacy, financial management and attitude towards saving. The other $37.8 \%$ may be contributed by the other factors in which could be considered in future research. However, the percentage of $62.0 \%$ confirms the predictability power of independent variables investigated in this study.

Table 7: Regression analysis

\begin{tabular}{llllll}
\hline Independent Variable & VIF & S.E & $\mathrm{t}$ & sig & Result \\
\hline Financial literacy & 1.583 & .240 & 3.633 & $.000^{*}$ & H1 = supported \\
Financial management & 1.753 & .470 & 6.773 & $.000^{*}$ & H2 = supported \\
Attitude towards savings & 1.531 & .226 & 3.479 & $.001^{*}$ & H3 = supported \\
\hline
\end{tabular}

Adjusted $\mathrm{R}^{2}=.620 ; \mathrm{F}$ value $=76.19 ;$ Durbin-Watson $=1.967$

*sig at 0.05

\section{Discussion}

The issue of financial wellbeing among employees has been well addressed in the literature as described in the introduction and problem statement of this paper. Acknowledging there is a gap in the literature in relation to the understanding on what factors may have a relationship with employee financial wellbeing, this study investigated three factors of financial wellbeing that are consistently highlighted in the literature namely financial literacy, financial management and attitude towards savings. Therefore using public servants in Malaysia, the regression analysis revealed that all independent variables understudy have significant relationship with financial wellbeing. The findings imply that if government targets to improve the financial wellbeing of public servants, action should be taken to improve their financial literacy, financial management and attitude towards savings. Action could be in the form of compulsory training session, open public talk, competency test for promotion or higher tax incentive for public servants contributing voluntarily to private retirement schemes.

H1 of this study are supported. In other words, this study confirmed the relationship between financial literacy and financial wellbeing does exist. The finding is consistent with ubiquitous evidence that available in the literature. Previous study such as Hsiao et al. (2016) documented the same findings. According to Hsiao et al. (2016) financial wellbeing of retirees are very much related to their level of financial literacy because be knowledgeable in financial related matters allow them to have a better financial planning for their retirement planning. In other words, financial literacy is not only about mastering knowledge on financial but the definition of literacy would imply that an individual has capability to use the financial knowledge effectively in helping them making decision in financial related matters such as buying assets, taking credit, investing in shares or subscribing insurance policy. As an effort to help the overindebted people out from their problem, Koloba (2018) suggest universities in South Africa to include financial literacy program for all students across the discipline. Another suggestion to improve the financial literacy was also documented by Gaisina \& Kaidarova (2017). According to them, the government is responsible in planning and executing program that are effective in increasing the level of financial literacy among public. In Malaysia, the Central Bank has established an agency namely the Credit Counselling and Debt Management Agency, among others to provide counselling to the public with financial distress as an effort to find way out of their problem. 
Nurul Najwa Wahab1 et al., Journal of Techno Social Vol. 10 No. 2 (2018) p. 50-59

This study also supported H2. In other words, financial management has significant relationship with financial wellbeing. Barbic et al. (2016) found that people who save for retirement is more likely to achieve financial wellbeing in the retirement days. In other words, individual who manage well their money and be prepared for retirement would be less likely to become dependent on others. In this study, the respondents were from public sectors with a permanent and long term employment. This secure condition should not be a reason for them to take financial management issue for granted. Instead they need different set of financial management (Ciemleja, 2016). As such, they should plan of subscribing insurance for minimizing the financial risk of accidents that are beyond their job benefits like unable to continue working due to health problem or accident while on personal overseas trip. These could lead to financial distress if financial is not well managed.

H3 of this study is also supported in which indicated the significant relationship between attitude towards savings and financial wellbeing. Individual with positive attitude towards savings would be more discipline in allocating their income into savings, usage on savings funds only for important needs and have a clear and long term objective of savings. In a study in Taiwan, Hsiao et al. (2016) reported that the positive attitude towards savings has a positive impact on retirement financial planning. They further revealed that the relationship is stronger than the relationship between financial literacy and retirement planning. The right attitude toward savings is critical because the objective of savings are varies from short term objective to long term objective. Among others, the objective of savings is to prepare adequate fund for sustaining and improving the quality of life. Having said this, savings would enable individual and family to pay for their consumption expenses, buying necessary good and venturing into new economic activities (Kozera et al., 2016). Having capability to pay for all these is an indicator of financial wellbeing of individual.

\section{Limitations and Suggestions for Future Research}

In this study, financial literacy and saving behavior were treated as unique independent variables, and the VIF value in regression analysis indicated there was no serious multicollinearity problem exists among the independent variables. However, future study would be useful to investigate financial literacy as predictor variable of saving behavior because how an individual behave in relation to financial matters is very much depend on the knowledge on the financial. Financial knowledge is one element of financial literacy (Nguyen et al., 2017). In addition, this study used public servants as respondents where pension is one the retirement benefits that exclusive for them and not to employees of private sectors. Therefore, future studies may consider to investigate the differences of financial wellbeing between public and private employees. Further, financial wellbeing is not a definite situation, it may changes due to the external economy and politic changes or changing in personal life. Although survey at one single point of time useful to gauge the financial wellbeing of individual, a longitudinal study may produce an interesting findings that may expand the boundary of knowledge.

\section{Conclusion}

Malaysia is soon will become an aging country where more population without active income lives. Therefore, this study highlighted the issue of financial wellbeing as an emerging challenge that needs quick response from researchers. This study has able to close the gap in the literature by surveying financial wellbeing among public servant in Malaysia. The findings suggest appropriate action to be taken before financial wellbeing become a burden to nation progress towards becoming of a developed nation. Although this study has successfully answered it research question and achieved its objective, few suggestions were listed as guidance for future research. Future research on the issue is a necessary as financial issue is becoming more complex from day to day due to the introduction of new financial products into market and the integration of internet technology into financial products.

\section{References}

Anthes, W. L. (2004). Financial illiteracy in America: a perfect storm, a perfect opportunity, Journal of Finance Service Professional, 58(6), 49-56.

Barbic, D., Palic, I. \& Bahovec, V. (2016). Logistic regression analysis of financial literacy implications for retirement planning in Croatia, Croatian Operational Research Review, 7, 319-331.

Ciemleja, G. (2016). Financial literacy of Latvian citizens: Findings and conclusion, Systemics, Cybernetics and Informatics, 14(4), 61-67.

Gaisina, S. \& Kaidarova, L. (2017). Financial literacy of rural population as a determinant of saving behavior in Kazakhtstan, Rural Sustainability Research, 38(333), 32-42.

Gasiorowska, A. (2015). The impact of money attitude on the relationship between income and financial satisfaction, Polish Psychological Bulletin, 46(2), 197-208. 
Grable, J. E., Park, J. Y. \& Joo, S. H. (2009). Explaining financial management behavior for Koreans living in the United States, Journal of Consumer Affairs, 43(1), 80-107.

Hair , J. F., Jr., Anderson, R. E., Tatham, R. L. and Black, W. C.(1995) Multivariate Data Analysis, 3rd Ed , Macmillan Publishing Company, New York

Hsiao, Y., Lin, S. \& Dambaravdan, C. (2016). Financial literacy, savings behavior, and retirement planning in Taiwan, Cross-Strait Banking and Finance, 4, 1-21.

Huston, S. J. (2010). Measuring financial literacy, Journal of Consumer Affairs, 44(2), 296-316.

Jappelli, T. \& Padula, M. (2015). Investmnet in financial literacy, social security and portfolio choice, Journal of Pension, Economics and Finance, 14(4), 369-411.

Jariah, M., Husna, S., Tengku Aizan, T. A. \& Ibrahim, R. (2012). Financial practices and problems amongst elderly in Malaysia, Pertanika Journal of Social Science \& Humanities, 20(4), 1065-1084.

Joo, S. \& Grable, J. E. (2004). An exploratory framework of the determinants of financial satisfaction, Journal of Family and Economics Issues, 25, 25-50.

Kaur, A., Mittal, N. \& Agarwal, S. (2013). Financial literacy of new job entrants, Pertanika Journal of Social Science \& Humanities, 21(2), 713-724.

Koloba, H. A. (2018). Access to credit and saving behavior of generation Y students, are we educating and overindebted generation? International Journal of Economics and Finance Studies, 10(1), 50-65.

Kozera, A., Glowicka-Woloszyn, R. \& Stanislawska, J. (2016). Savings behavior in households of farmers as compared to other socio-economic groups in Poland, Journal of Agribusiness and Rural Development, 4(42), 557-566.

Kulikov, D., Paabut, A. \& Staehr, K. (2007). Factors affecting household saving behavior in Estonia, Kroon \& Economy, 2, 28-42.

Lusardi, A. (2008). Financial literacy: An Essential Tool for Informed Consumer Choice, NBER Working Paper.

Mohamad, F. S. \& Teo, T. J. (2014). The influence of financial literacy, saving behavior, and financial management on retirement confident among women working in the Malaysian public sector, Asian Social Science, 10(14), 40-51.

Nguyen, T. A. N., Rozsa, Z., Belas, J. \& Belasova, L. (2017). The effects of perceived an actual financial knowledge on regular personal savings: case of Vietnam, Journal of International Studies, 10(2), 278-291.

Ntsalaze, L. \& Ikhide, S. (2016). Household over-indebtness: Understanding its extent and characteristics of those affected, Journal of Social Science, 48(1-2), 79-93.

Pierce, C. \& Hanna, S. (1996). Financial stress, social support and alcohol involvement: A longitudinal test of the buffering hypothesis in a general population survey, Health Psychology, 15, 38-47.

Pudlo, P. \& Gavurova, B. (2012). Experimental learning in higher education, using simulation games as learning tool, 12th International Multidiisplinary Scientific Geoconference, Vol III, Book Series, 1093 - 1100.

Sabri, M. F. \& Juen, T. T. (2014). The effects of financial literacy, financial management and saving motives on financial well-being among working women, Journal of Wealth Management \& Financial Planning, 1, 20-32.

Shusha, A. (2016). The mediating role of rational buying in the relationship between financial literacy and financial wellbeing, Research Journal of Finance and Accounting, 7(3), 133-142.

Sood, P. B., Choudhary, K. \& Singh, H. (2012). Role of financial education for future technocrat, Pertanika Journal of Social Sciences \& Humanities, 20(4), 1341-1350.

Zemtsov, A. A. \& Osipova, T. Y. (2015). Financial wellbeing as a type of human wellbeing: Theoretical review, The European Proceedings of Social \& Behavioural Sciences, 385-392. 
Nurul Najwa Wahab1 et al., Journal of Techno Social Vol. 10 No. 2 (2018) p. 50-59 